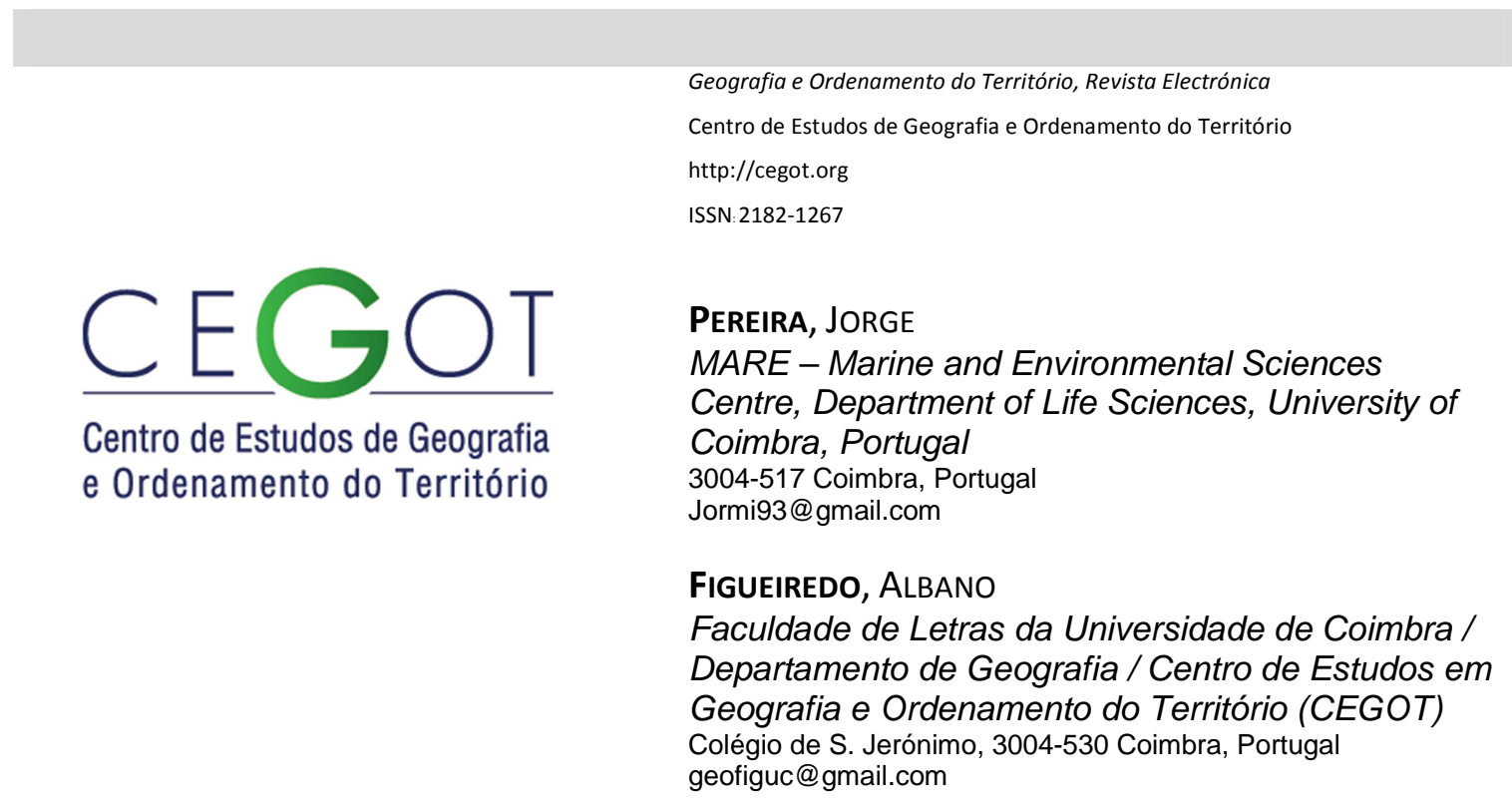

\title{
Assessing suitable area for Acacia dealbata Mill. in the Ceira River Basin (Central Portugal) based on maximum entropy modelling approach
}

\begin{abstract}
Avaliação da área adequada para Acacia dealbata Mill. na Bacia do Rio Ceira (Centro de Portugal) com base em modelação suportada no princípio da máxima entropía
\end{abstract}

Referência: Pereira, Jorge; Figueiredo, Albano (2015). Assessing suitable area for Acacia dealbata Mill. in the Ceira River Basin (Central Portugal) based on maximum entropy modelling approach. Revista de Geografia e Ordenamento do Território (GOT), n.o 8 (dezembro). Centro de Estudos de Geografia e Ordenamento do Território, p. 171-190, dx.doi.org/10.17127/got/2015.8.009

\begin{abstract}
Biological invasion by exotic organisms became a key issue, a concern associated to the deep impacts on several domains described as resultant from such processes. A better understanding of the processes, the identification of more susceptible areas, and the definition of preventive or mitigation measures are identified as critical for the purpose of reducing associated impacts. The use of species distribution modeling might help on the purpose of identifying areas that are more susceptible to invasion. This paper aims to present preliminary results on assessing the susceptibility to invasion by the exotic species Acacia dealbata Mill. in the Ceira river basin. The results are based on the maximum entropy modeling approach, considered one of the correlative modelling techniques with better predictive performance. Models which validation is based on independent data sets present better performance, an evaluation based on the AUC of ROC accuracy measure.
\end{abstract}

Keywords: susceptibility to invasion, maximum entropy, species distribution modelling, GIS. 


\section{RESUMO}

A ocorrência de processos de invasão biológica por organismos exóticos tornou-se um problema importante na atualidade, uma consequência dos impactes que the têm sido associados em vários domínios. Tendo em conta a escala e magnitude destes processos, revela-se como prioritário um investimento crescente na melhor compreensão destes processos, na identificação de áreas mais suscetíveis, e na definição de medidas de prevenção e mitigação como forma de reduzir os impactes associados. Este trabalho pretende apresentar resultados preliminares na avaliação da suscetibilidade à invasão pela espécie exótica Acacia dealbata Mill. na bacia do rio Ceira. Os resultados estão baseados na utilização de uma técnica de modelação suportada no princípio da máxima entropia, considerada uma das mais robustas entre as técnicas de natureza correlativa. Em termos de resultados, verifica-se que os modelos cuja validação é feita com base em amostra independente apresentam melhor desempenho em termos preditivos, uma avaliação baseada na medida AUC de ROC (Area Under the Curve of the Receiver-Operating Characteristic).

Palavras-chave: suscetibilidade à invasão, máxima entropia, modelos de distribuição de espécies, SIG.

\section{Introduction}

As we know, natural phenomena and all processes associated with nature are too complex to be simplified and replicated accurately through modelling. Thus, uncertainty is necessarily inherent to any model that aims to duplicate natural processes. Despite such handicap, the increasing availability of environmental data, such as high-resolution digital maps, and software development supported the growing and wide use of predictive modelling, namely statistical bioclimatic models, also known as "habitat suitability models" or "ecological niche-based models" (Guisan \& Zimmermann, 2000). The use of such models on different fields, such as conservation, assessment of impacts from climate change, endemic species prospection, among others (for a revision see Figueiredo, 2013), contributed decisively to reduce the importance of related uncertainties, namely variability on modelling results. Despite the fact that weaknesses were reduced, and methodological strategies can be implemented in order to cope with, models should always be under high scrutiny. In fact, detailed analysis of models will certainly drive to a better application of 
results, conscious about limitations, and do not challenge their usefulness, namely on drawing paths for solving problems related to spatial planning (Anderson, et al., 2003).

The aim of this paper is to assess the performance of a modelling technique, based on the maximum entropy approach (MAXENT), to predict the potential distribution of the alien Acacia dealbata Mill. in the Ceira river basin.

\subsection{The biological invasion issue}

Many of the plants that surround us in our daily lives are exotic, brought by man from its native habitat (Williamson \& Fitter, 1996), a process deeply enhanced by the intensification of world trading (Vilá et al., 2008). Introduced intentionally or accidentally (García-Berthou, 2008; Vilà et al., 2008), not all became invasive (Lowry et al., 2013). In fact, only a small fraction of exotic species gets naturalized, and only a small portion of those exhibits an invasive response (Richardson et al., 2014), once they can effectively reproduce and spread widely and far away from the location where they originally were introduced without human aid, greatly enhancing their distribution (Sala et al., 2000; Richardson et al., 2000; Simberloff et al., 2013; Blackburn et al., 2014). It is widely accepted that such a response usually is dependent on a stimulus event (Figure 1), which is often unpredictable and of diverse origin (Marchante et al., 2008; Marchante et al., 2014). The effect is identified by an exponential increase on distribution and population size (Vilá et al., 2008), based on the production of fertile offspring in large numbers and dispersion far beyond the parent plant, with potential to occupy large areas on semi-natural, or even natural, habitats. The large amount of seeds produced, viable for a long time on seed bank, very often is combined with appetency for vegetative propagation, or disperse very easily and in large quantities, and benefit from the absence of natural enemies (Marchante et al., 2008; Marchante et al., 2011; Marchante et al., 2014). 


\section{Population size}

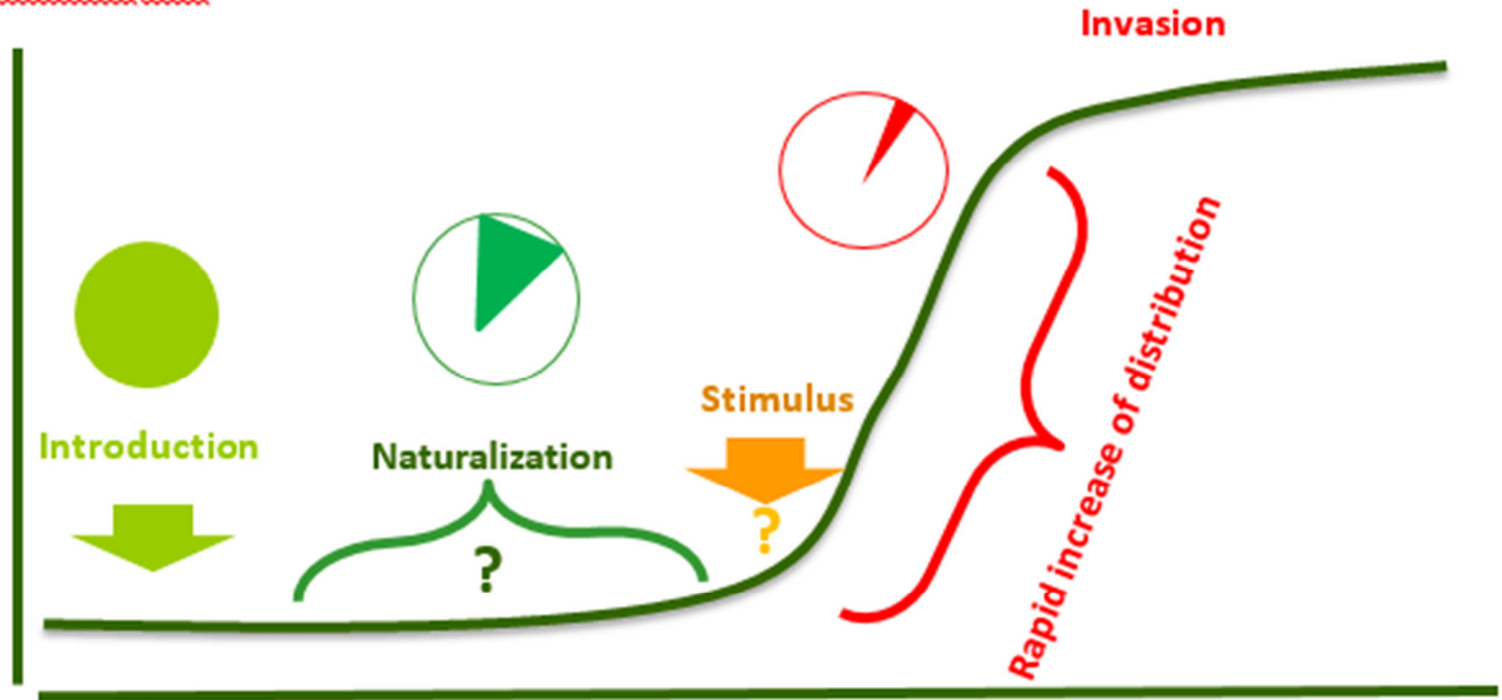

Time

Figure 1 - Main stages of a biological invasion process.

Source: Adapted from Marchante et al., 2008; Marchante et al., 2014.

Currently invasion processes are identified as one of the major threats to global world, a result of the impacts described in several areas like economy, water availability, public health, biodiversity, etc (Pimentel, 2002; MEA, 2005). The magnitude of the negative impacts associated to such threat demand an effort dedicated to monitoring the invasion status and territorial susceptibility, information that's essential to identify measures to mitigate the impacts (Graham et al., 2004; Vilà, et al., 2010). The issue of invasive species is relatively recent for scientific research, and supports the need for further studies based on inter and multidisciplinary cooperation in different scientific domains. Such approach is critical for a full understanding of the invasive potential of exotic species, improving knowledge about the processes, critical for setting mitigation and control measures, and helping on the identification of highly susceptible areas, a fundamental task for the application of preventive measures. Habitat predictive modelling performs a tool that is definitely appropriate to assess the susceptibility of a territory to invasion. 


\subsection{Habitat Predictive Modelling}

Improvements in the capacity to collect, manage and store large amounts of data, namely high resolution environmental predictors, gave an important contribution to the quantification of organism-environment relationships, an issue that gained great attention with the emergence of the habitat predictive modelling. Computing advances on GIS tools were determinant, not only in the modelling process itself, but also in the possibility of creating new data, such as current distribution for an organism, for data storage purposes and manipulation of geographic databases, namely environmental variables considered critical for the explanation of species' distributions (Castro, 2004). Habitat predictive modelling is based on the correlation found between the occurrences of an organism for a territory and a set of environmental variables (Peterson, 2003). Under such approach, the exploration of such relationships benefited from the development of different quantitative modelling techniques, all rooted in the concept of ecological niche (Elith et al., 2006; Ortega-Huerta, 2008; Soberón, 2010). Such diversity of modelling techniques supported the rise of a critical issue, the great variability of modelling results (Araújo \& Guisan, 2006), derived from differences on mathematical assumptions, or from decision-making, such as differences on parameterizations or assumptions (Liu, et al., 2005; Pearson et al., 2006; Araújo \& New, 2007; Liu et al., 2013). But such kind of variability can actually be mitigated, by implementing an ensemble forecasting approach supported on different modelling methods (Araújo \& New, 2007).

The wide use of niche-based models on studies focused on assessing susceptibility to invasion or suitable areas for alien exotic species during the last two decades indicates the importance of such issue (Gutierres et al., 2011; Vicente, 2012), and reveals the accepted efficacy of such approach to improve our knowledge about invasiveness and invisibility. 


\section{Methodology}

\subsection{Study area}

Ceira river is a small tributary of Mondego river, located in the Centre Region of Portugal. Its basin has $7084 \mathrm{Km}^{2}$, and is entirely installed on the Hercynian massif, a territory dominated by schistous rocks. In the basin, altitude ranges from $82 \mathrm{~m}$ (intersection with Mondego river) to $1300 \mathrm{~m}$ near Seia (Figure 2).

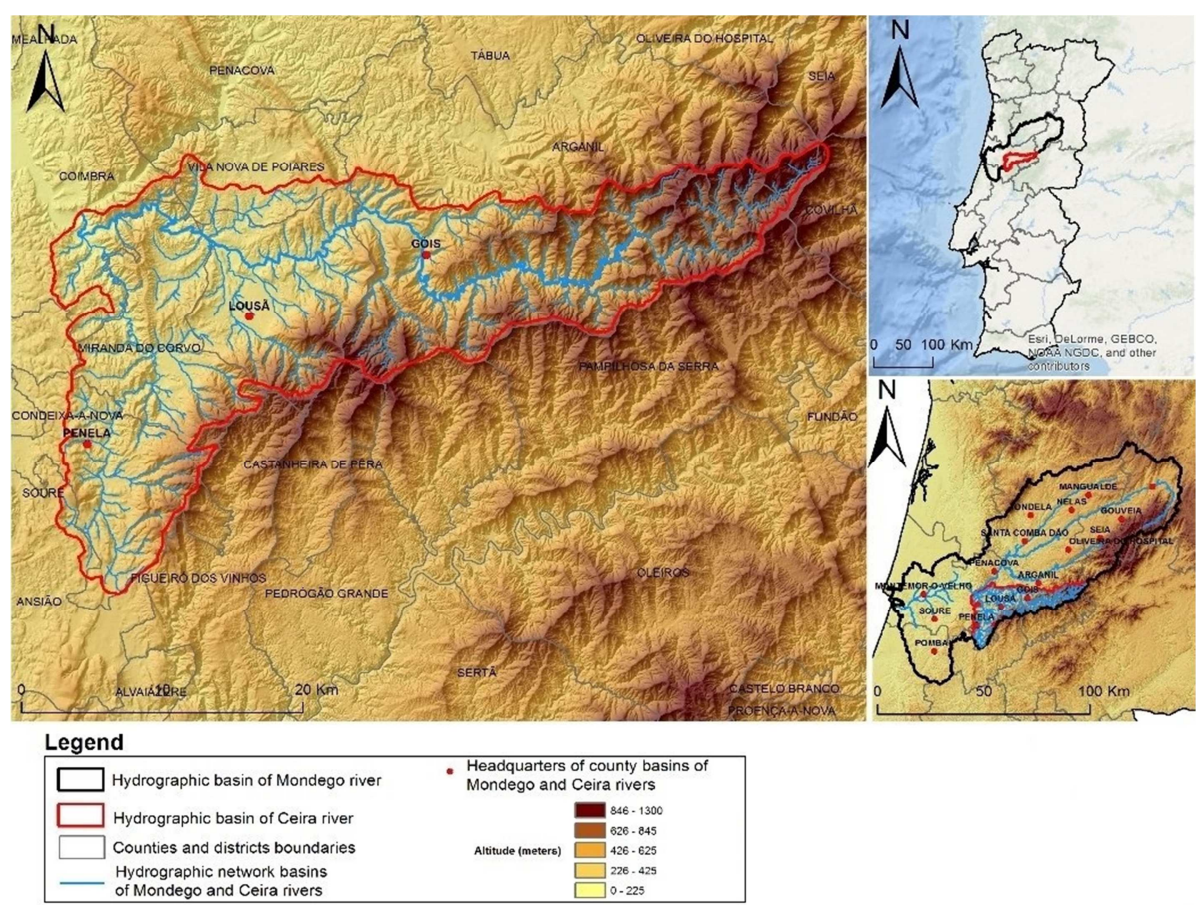

Figure 2 - Location of the Ceira River within Mondego river basin. Vetorial data source: IGEOE (Instituto Geográfico do Exército).

Climate in the Ceira river Basin clearly exhibits a Mediterranean pattern, with a hot summer dry season that lasts from June to September. The driest months are July and August, with average rainfall around $15-20 \mathrm{~mm}$, while during winter months rainfall is around $150-180$ $\mathrm{mm} / \mathrm{month}^{1}$.

\footnotetext{
${ }^{1}$ According to climatic series for the period 1961-1990, based on the Lousã meteorological station - Instituto Português do Mar e da Atmosfera.
} 


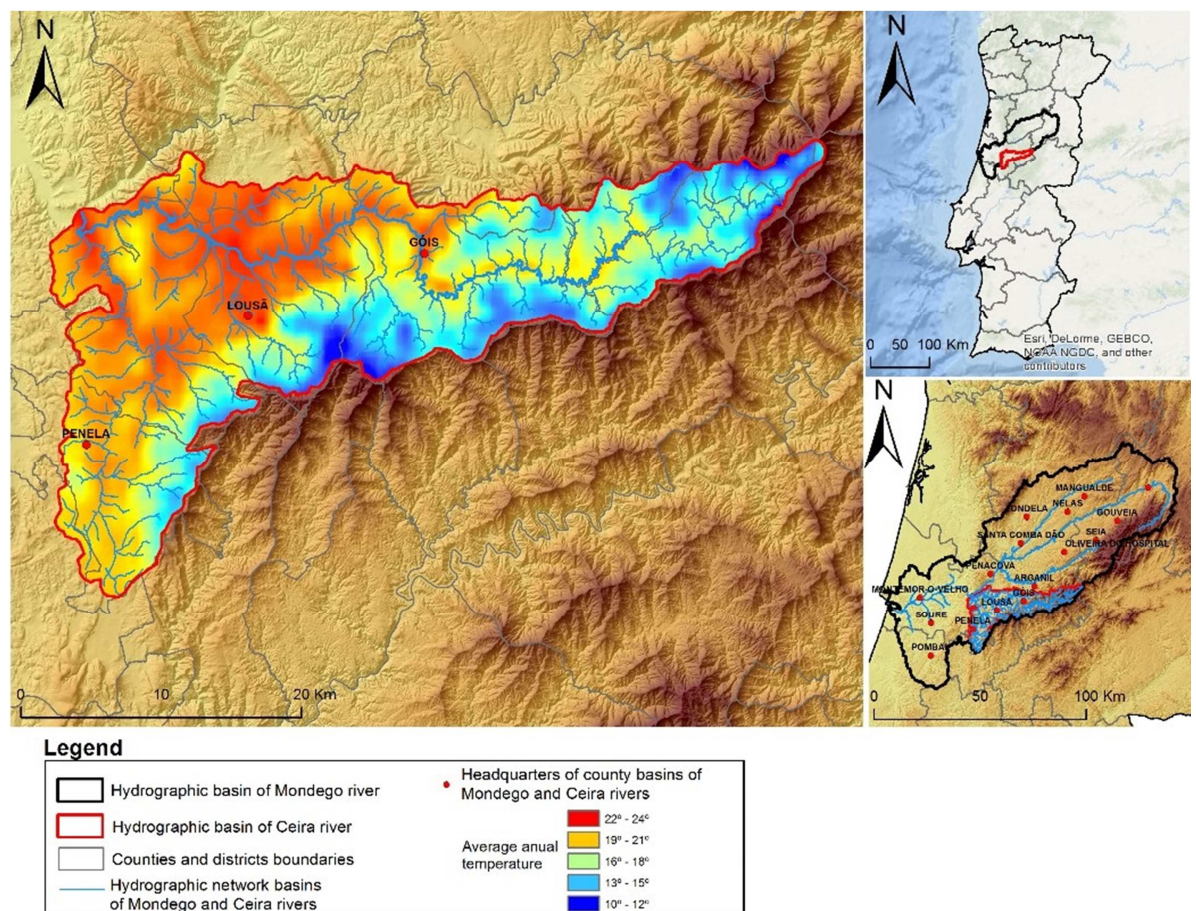

Figure 3 - Spatial patterns of mean temperature of the warmest month on study area.

Bioclimatological data source:

http://home.isa.utl.pt/ tmh/aboutme/Informacao_bioclimatologica.html (Monteiro-Henriques, 2010)

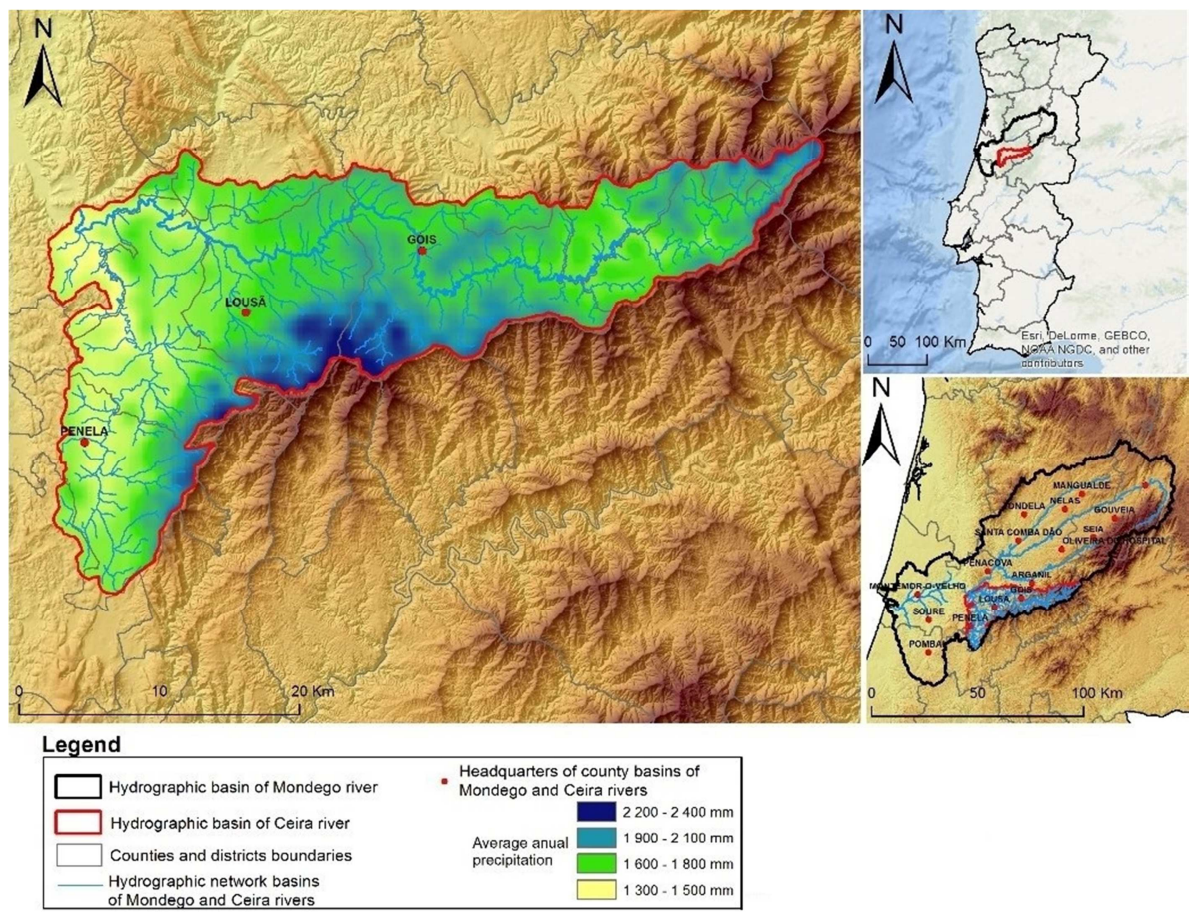

Figure 4 - Spatial pattern for annual average precipitation on the study area. Bioclimatological data source:

http://home.isa.utl.pt/ tmh/aboutme/Informacao bioclimatologica.html (Monteiro-Henriques, 2010) 
In response to the altitudinal gradient, water stress decreases with increasing altitude, once climate becomes progressively more humid, reaching a super-humid condition with small deficiency of water at the higher summits of Lousã mountain range. Spatial patterns for precipitation and temperature clearly exhibit a strong correlation with altitudinal variation. Areas of higher altitudes register the highest values of annual precipitation (Figure 4) and lower temperatures, both in mountain areas. On the contrary, areas of lower altitude register the lowest values of precipitation and higher average temperatures, especially during summer (

Figure 3). In terms of land use and land cover, it is clear the dominance of a forest $(90 \%)$ (Figure 5) that is dominated by exotic trees, namely eucalyptus plantations. Urban area, associated to villages and small towns (Lousã, Gois, Arganil and Miranda do Corvo) occupies only $0,5 \%$ of the basin, while agriculture reaches almost $10 \%$ of the study area.

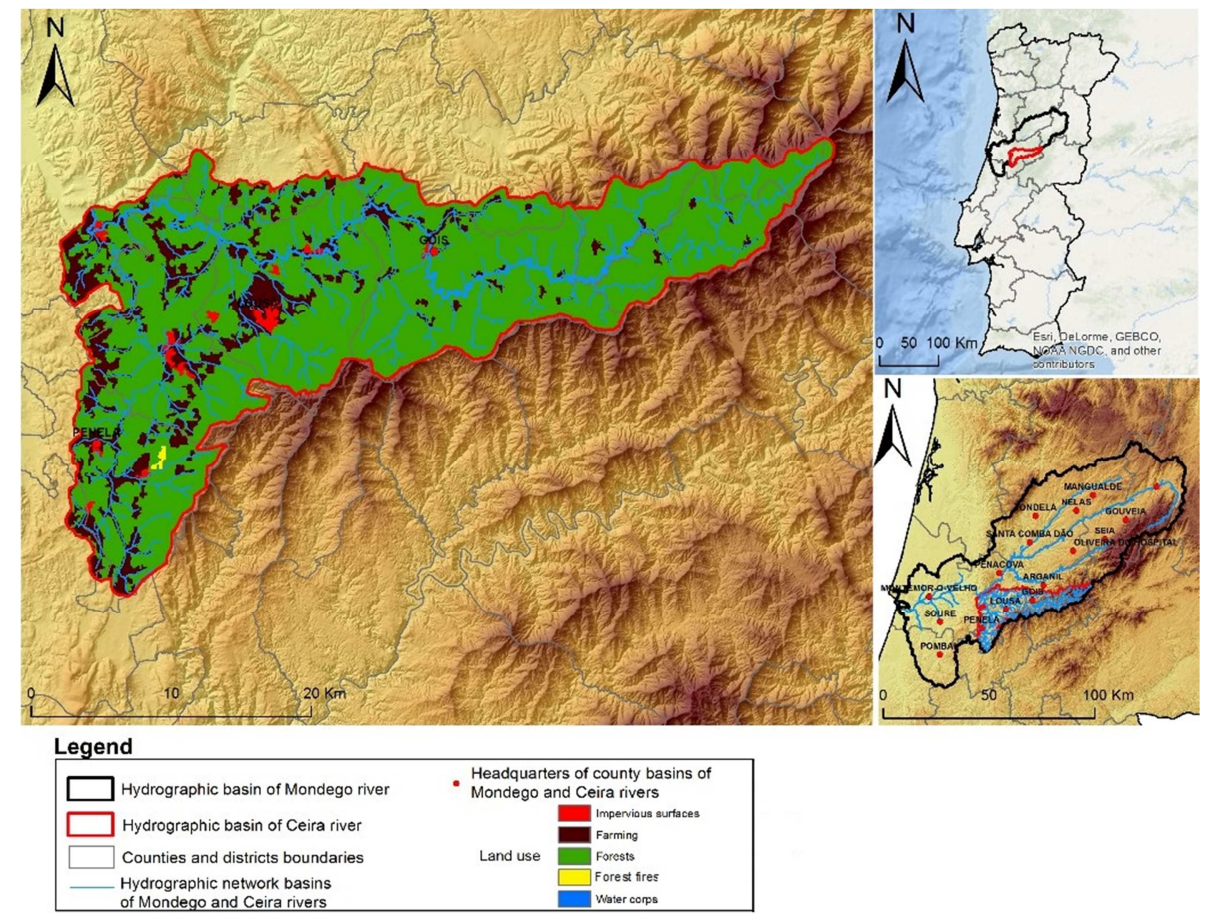

Figure 5 -Land use and land cover at the Ceira river basin.

Land-use data source: Carta de Uso e Ocupação do Solo de Portugal Continental - COS2007 nível 2 (DGT, 2007). 


\subsection{The Ecology of Acacia dealbata}

Some of the species identified as invasive in Portugal have already a significant area of occurrence, exhibiting an intrinsic capacity to adapt to significant environmental gradients. Among those species, Acacia dealbata is commonly considered one of the most problematic, considering the occupancy area and potential to invade new areas (Marchante et al., 2014). This paper has for reference such species, considered one of the alien invasive species with larger covered area in the Portuguese mainland, and with large implantation on the Ceira river basin (Pereira \& Figueiredo, 2015). Native from Southeast Australia and Tasmania, it is a tree that can grow up to 15 meters, with perennial and bipinnately compound leafs (2- $12 \mathrm{~cm}$ long), fragrant bright yellow flowers grouped into chapters (5$6 \mathrm{~mm}$ ) that form large panicles and reddish-brown pods (Paiva, 1999). Introduced for ornamental purposes and to prevent erosion, it presents a wide distribution in mainland Portugal (Marchante et al., 2014), a pattern resultant from its wide use in the past and a subsequent spontaneous spread to other areas, a consequence derived from its potential to occupy different types of habitats. Such success is based on the high production of seeds, which remain viable in the soil for many years. Germination is stimulated by fire, vigorously sprouts from root and form very dense spots, performing a situation of high competition, usually not tolerated by native species. In fact, such disadvantage for native species is also associated to allelopathic effects (Lorenzo et al., 2008). In terms of invaded areas, the species occurs on a significant range of environmental conditions, from deep soils on valleys, mountain areas and edges of waterways and roads (Pysek et al., 2004).

\subsection{Modelling process}

The assessment of suitable areas for Acacia dealbata in the Ceira river basin is supported on the use of a modelling technique based on the maximum entropy approach (MAXENT). Such modelling technique presents a forecast based on the probability distribution of maximum entropy, supported on a correlation between the presence of the organism (occurrences) and a set of predictor or explanatory variables (Phillips et al., 2006; Elith et al., 2011). The selection of a modelling method grounded on the maximum entropy principle is based on the good results in terms of performance comparing to other predictive modelling methods 
of correlative nature (Elith et al., 2006), namely its robustness facing changes on parametrizations (Figueiredo, 2008). In addition, it is a presence-only method; an attribute that fits the idea that the use of absence data in heavily disturbed environments by human activity might reduce the accuracy of models results (Manel et al., 2003), especially in the case of exotic invaders, which are not in equilibrium with environmental conditions (Figueiredo, 2013). More than the high level of disturbance from human activity, the low importance of absence data is related to the fact that the organism very often seems to be more controlled by a balance between dispersal and time of introduction, and do not reflect unsuitable ecological conditions. Such framework clearly indicates a situation where the use of absences holds a questionable value for the accuracy of models results. Despite the fact that absence data is not provided, the software in use (MAXENT) creates a set of background points to use as pseudo-absences for calibration purposes, selected on sites with opposite environmental conditions to those identified as suitable for the species.

In order to assess the influence of different parameterizations on models results, different combination of parameters have been considered during modelling procedures.

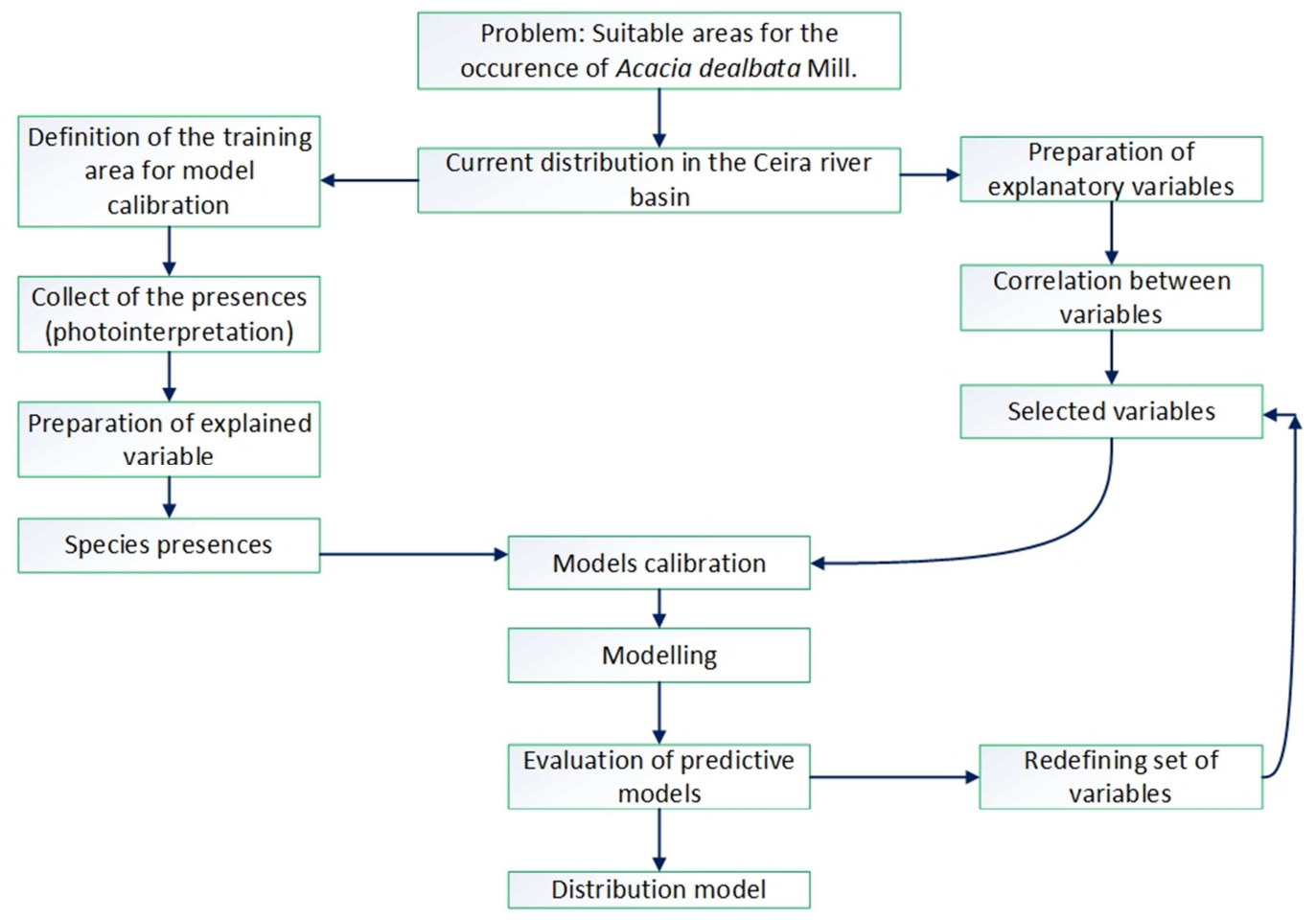

Figure 6 - Flowchart of the modelling process. 


\subsection{Models calibration and accuracy}

Occurrences data used for calibration purposes was collected by interpretation of aerialphotography, based on a grid cell with a resolution of $200 \times 200 \mathrm{~m}$, and validated in the field. In order to obtain models with higher predictive performance, different methodological strategies were implemented, namely different combinations of environmental predictors and validation with dependent (30\% of collected occurrences from photo-interpretation) or independent data sets (occurrences collected in the field during validation of data for presences collected from aerial photography). In terms of environmental predictors, models were calibrated using a subset of predictor variables, based on the assumption that the type and number of environmental predictors used on models calibration is a critical issue for modelling results (Araújo \& Guisan, 2006). In order to evaluate how different combinations of predictors affect predictive accuracy, different groups have been set. Only 3 models have been calibrated using all the environmental predictors, and 3 others have been calibrated using only a subset of variables which selection was based on criteria that guarantee that only environmental variables with predictive capacity are selected, discarding those that have low predictive capacity or duplicate patterns. Selection was based on multivariate correlation (Spearman Rho) and jackknifing (integrated in MAXENT software) approaches. The second approach allows discriminating the contribution of each variable, in order to select the variables that show best predictive potential. The first approach (correlation) supported the elimination of variables with strong correlation among them $(>-/+0.7)$, avoiding redundant variables, namely problems with multicollinearity (Graham, 2003). The application of such criteria selected the following variables: $\mathbf{P}_{\mathbf{S}} \mathbf{S}$ (annual precipitation on a dry year), Alt (altitude), Slope and Tmx (mean temperature of the warmest month). The exclusion of the other variables on such group because of strong positive correlation is a strategy implemented to reduce the skewing effect on results derived from spatial autocorrelation of variables (Dormann et al., 2007). The absence of abiotic and dispersion data for calibration purposes determines that results must be interpreted in the sense of potential distribution (see Soberón, 2010). Spatial resolution for environmental variables is set in compatibility with resolution used during occurrences survey (200x200m). In terms of models accuracy, performance can be assessed using threshold-dependent or independent measures (Freeman \& Moisen, 2008). In order to avoid the threshold interference in the evaluation of models performance, the results are evaluated using the AUC of ROC (Area Under the Curve of the Receiver Operating Characteristic), a threshold-independent statistical measure (Pearson et al., 2006). This accuracy measure is accepted as suitable for assessing the performance of the models, since it assesses the model's ability to 
discriminate suitable from unsuitable conditions (Lobo et al., 2008). It is a statistical measure that ranges between 0.5 and 1 , where value 1 indicates perfect discrimination ability and 0.5 indicates a low discriminatory capacity of the model. AUC $>0,9$ indicates a very good discriminatory ability (Engler et al., 2004). Despite the fact that is independent on the threshold used for assessing models performance, and unaffected by the number of presences used for calibration (Liu et al., 2013), the use of such measure is not excluded from limitations (Lobo et al., 2008).

The presentation of results is based on a process of binarization, in order to present outputs that distinguish only suitable from unsuitable conditions. Such process is based on two different thresholds, both giving more importance to presence data used on calibration:

i) Maximum test sensitivity and specificity: a threshold that maximizes the model's ability to correctly predict the presences used on models calibration, reducing the omission rate and balancing predicted area, preventing overestimation; ii) Minimum training presence: enhances the presence in detriment of pseudo-absences, reducing the omission rate. Despite the potential trend to produce overestimations in terms of predicted area, such weakness is less important in the case of exotic invasive organisms, once their distribution is not in equilibrium with ecological conditions. In fact, the use of the lowest probability value associated to an occurrence, in order to distinguish suitable from unsuitable areas, seems to be adequate when the target organism keeps enlarging, ecologically and geographically, the occurrence area at the country level, as occurs with Acacia dealbata.

\section{Results and discussion}

In terms of results, models present a similar spatial pattern in terms of areas identified as suitable for Acacia dealbata in the study area, even when comparing the model with the best predictive accuracy and the one with worst performance (Table 1, Figure 7). The model with worst performance (Table I - model 8; Figure 7 - A) has an AUC (0.6), revealing lower capacity to discriminate suitable from unsuitable conditions. That might be the reason for selecting wider areas as suitable for the species, despite the fact that it does not predict as suitable areas where occurrences were recorded. The lower predictive accuracy can be related with specific decisions in terms of parameterization, namely the reduction of variables to a small set. The analysis of results also detected that it is useful to discard variables that have low predictive power, despite the absence of significant correlation with others. Such is the case of "distance to rivers (D_r)", which inclusion on predictors set used 
for calibration resulted on lower predictive accuracy when compared with models where the variable is discarded (Table I), confirming that the type of variables used on calibration might affect the performance of the models (Mcpherson et al., 2004; Hernandez, et al., 2006; Arenas, et al., 2014). In fact, there is significant variability in terms of models performance, considering AUC values (Table I), related to differences on parameterizations. Another parameter that has interference on the evaluation of models accuracy is the use of an independent data set for validation purposes. In fact, the model with the best predictive accuracy (AUC 0.87) (Table I - model 11; Figure 7 - B) is associated to the use of an independent data set (647 occurrences collected in the field), a parameter that guarantees higher AUC scores among models (Table I).

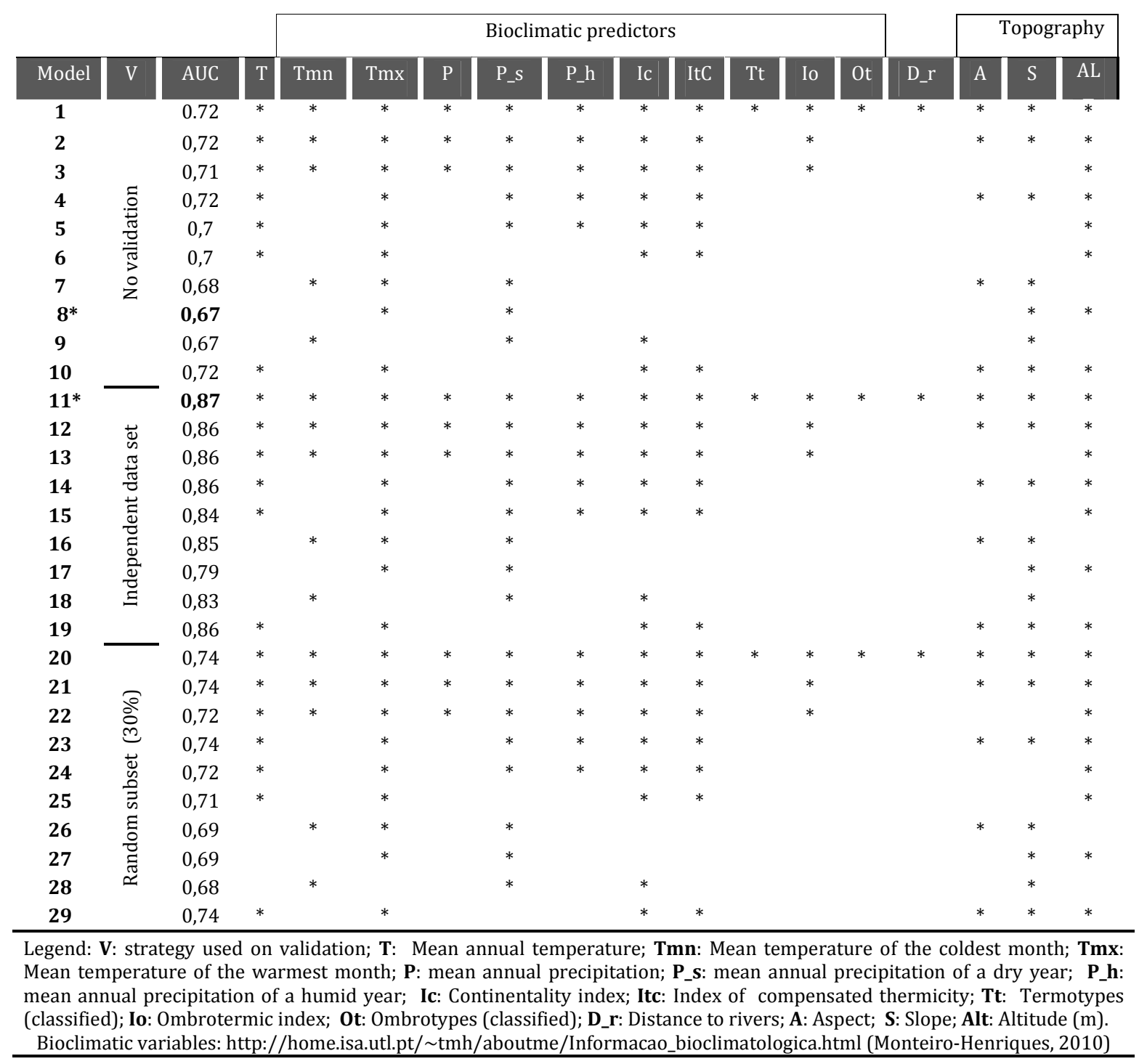

Table I - Results for models accuracy (AUC of ROC) and predictors used on calibration. 
Despite differences in terms of predictive accuracy, the significant majority of the models produce spatial predictions with high spatial coincidence, an aspect that might be interpreted as indicative of robustness for the models produced. But there are significant differences in terms of spatial predictions when comparing the model with lower predictive accuracy (Erro! A origem da referência não foi encontrada. 7 - A) to the one with higher AUC score (Figure 7- B).
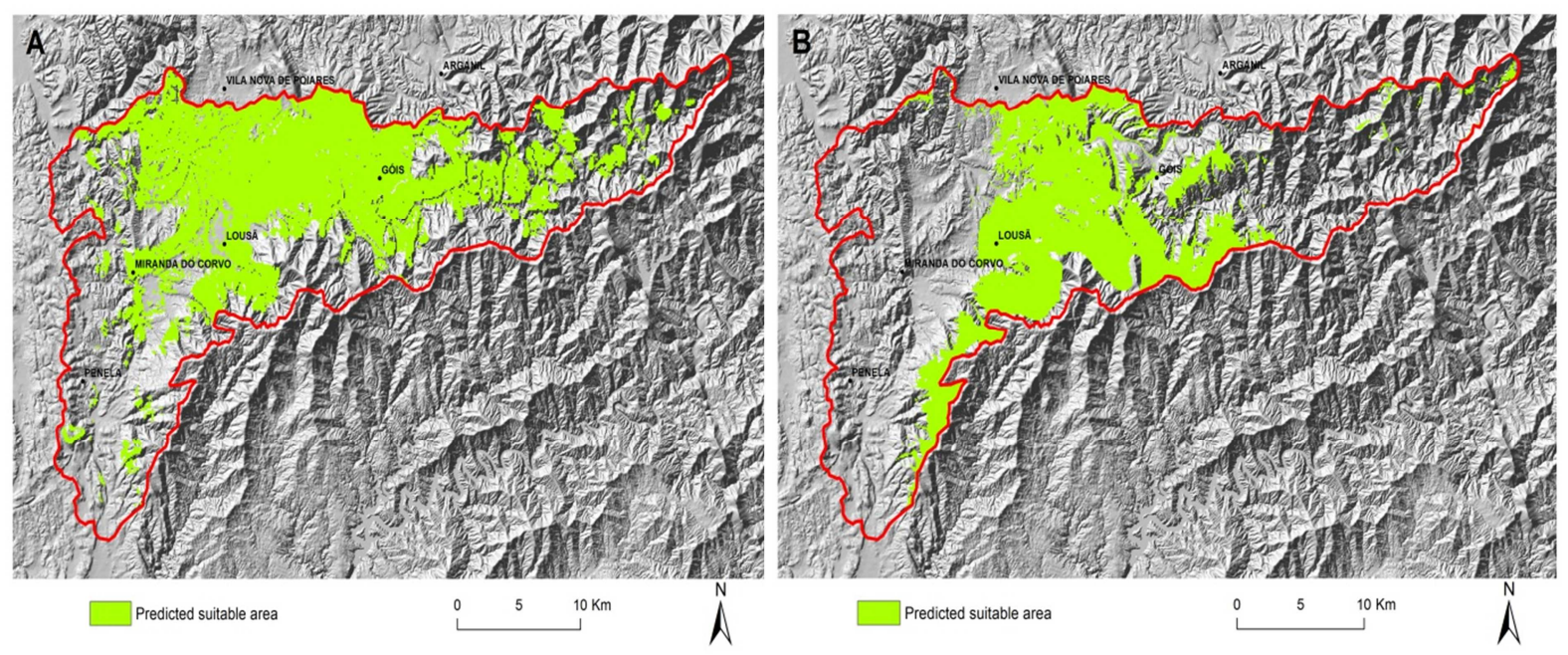

Figure 7 - Predicted suitable area for Acacia dealbata in the study area: model with worst performance (A); model with best performance (B). Binarization based on Maximum training sensitivity plus specificity.

On the other hand, models might be considered conservative, based on the fact that predicted area has a spatial definition that highly fits current distribution, a fact that is likely associated to the correlative nature of the models.

The predicted area classified as suitable includes a significant ecological range, considering variables used on calibration. In fact, current occurrences are associated to significant range in terms of altitude (30-1307 m.s.l.), average minimum temperature $(3-10 \circ \mathrm{C})$, and annual average precipitation $(956-1790 \mathrm{~mm}$ ). Another feature that is common among the models is the fact that precipitation is usually selected as the variable with high contribution to explain current distribution patterns, a fact that explains the high score that usually reaches in terms of relative contribution to the models. Considering the best model (model 11), the spatial pattern associated to the annual precipitation on a dry year (PP_sec) is the variable 


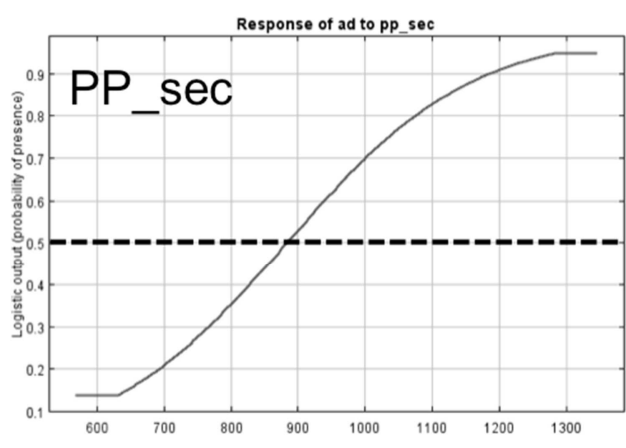

Response of ad to slope

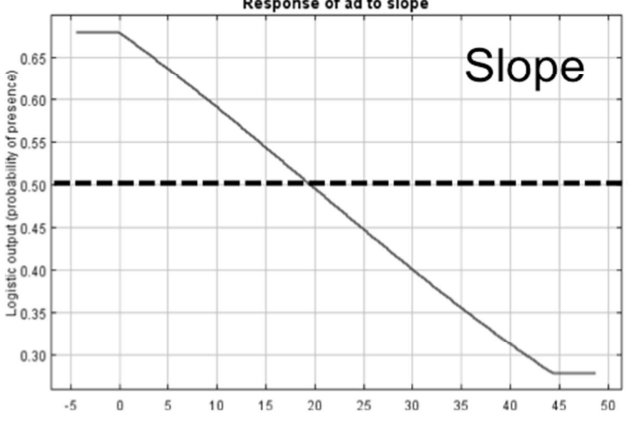

Response of ad to alt

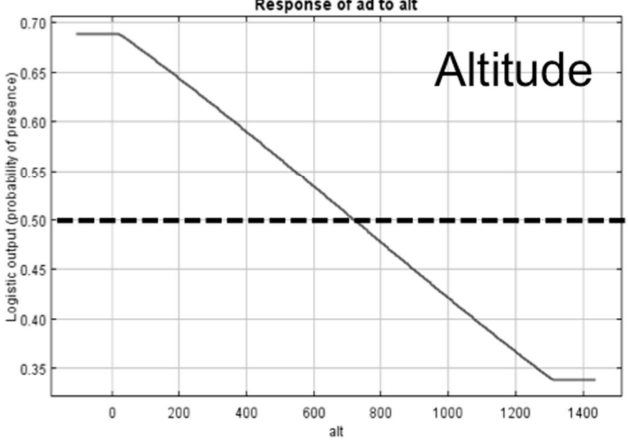

Figure 8 - Curve responses for predictors that have significant contribution to the best model that has the highest score, contributing about $70 \%$ for the model. The analysis of the response curves indicates that suitability is low for areas where values for such variable are under $800 \mathrm{~mm}$. Once annual precipitation values are usually higher than $900 \mathrm{~mm}$ in the study area, the lower values associated to a dry year might perform critical for the presence of the species. Despite the lower contribution to the model $(11 \%)$, slope is also identified as an environmental variable with predictive power. Notwithstanding the common use of Acacia dealbata to prevent erosion, usually on areas with higher slopes, the analysis of the response curve indicates that higher suitability is actually found on slopes lower than 20 , a result that clearly points to the high importance that invasion represents on areas outside those of earlier introduction. And despite the fact that temperature is not identified as determinant, the model identifies as suitable areas with mediterranean climatic pattern, namely those with more than two dry months (lower termomediterranean to lower supramediterranean), excluding areas which climate exhibits a more clear temperate pattern, namely a shorter dry season. But considering that the organism is an exotic species, which is not in equilibrium with environmental conditions, the absence on such areas might be rather determined by the fact that it had not enough time to reach them than a simple question of unsuitable conditions. In fact, only few individuals are currently present at or near the summits, areas that did not registered the introduction of the organism, namely for erosion control. In fact, the species is mostly found under $800 \mathrm{~m}$ a.s.l. (Figure 8).

The area predicted as suitable do not strictly follows the pattern exhibited by climatic variables, and results clearly exhibit the shape of current distribution patterns, a fact associated to the correlative nature of the technique in use. Although satisfactory capacity 
to discriminate suitable from unsuitable conditions by the models, their correlative nature limits their own ability to produce predictions for alien exotic organisms outside ecological conditions associated to known occurrences, especially on areas with significant ecological gradients.

\section{Conclusions}

The type of variables and critical decisions become determining factors for models results, a conclusion clearly supported by this study. The capacity to discriminate suitable from unsuitable areas is variable among models, a result related to differences on parameterizations. Considering the potential of habitat suitability modelling results to support decisions associated to spatial planning, and assuming the variability associated to changes on parameterizations, it is always advisable to contemplate the use of different scenarios, and do not rely on a specific combination of parameters. Such assumption is even more relevant in the case of alien invasive species, which non-equilibrium status with environmental conditions is more susceptible to promote variability on models results depending on data features or predictor variables. Thus, would be also advisable to produce results based on different modelling methods. Despite such weakness, this study clearly points to the fact that habitat suitability models contribute to improving our capacity to explore current distribution patterns of alien invasive species. But for such type of organisms, the usefulness of such results assumes a very limited time-horizon. In the case of exotic species, the models produced today must be updated at medium term, a conclusion based on the assumption that some habitats where the organism is absent now might be suitable, and new occurrences collected for those habitats can change drastically a suitability map in the near future. But even conservative, such results are useful, once they can focus the attention to areas that are more susceptible to invasion, supporting the definition of preventive measures spatially coherent. Methodology used to collect occurrences in this study seems to be an appropriate approach that helps on reducing bias 
from sampling, once it ensures equal effort on all the study area. However, it increases the chance for false absences, considering the ineffectiveness on detecting isolated individuals. Uncertainty associated to habitat suitability modelling should never block the use of such approach. Instead, such weakness should always be clearly accepted, and the interpretation of results should have by reference the framework associated to the modelling process as a all, considering not only the data used on calibration and the modelling technique in use, but also the decisions taken throughout the process. In fact, such approach performs a significant advance on our capacity to explore relationships between environmental predictors and the distribution of organisms, with a great advantage associated to the capacity to analyze spatial patterns.

\section{Aknowlegments}

The authors thank the two anonymous reviewers for valuable and constructive comments, which definitely contributed to enhance the earlier version of this paper.

\section{References}

ANDERSON, Robert., LEW, Daniel and PETERSON, Andrew. Evaluating predictive models of species distributions: criteria for selecting optimal models. Ecological Modelling, 2003, 162: 211.

ARAÚJO, M.B., GUISAN, A.. Five (or so) challenges for species distribution modelling. Journal of Biogeography. 2006, 33 (10): 1677-1688.

ARAÚJO, Miguel and NEW, Mark. Ensemble forecasting of species distributions. TRENDS in Ecology and Evolution, 2007, 22(1): 42-46.

ARENAS, Carlos., GUEVARA, Roger., MARTíNEZ-MEYER, Enrique., MANDUJANO, Salvador and LOBO, Jorge. Predicting species abundances from occurrence data: Effects of sample size and bias. Ecological Modelling, 2014, 294: 36-38.

BLACKBURN, Tim., ESSL, Franz., EVANS, Thomas., HULME, Philip., JESCHKE, Jonathan., KUHN, Ingolf., KUMSCHICK, Sabrina., MARKOVÁ, Zuzana., MRUGATA, Agata., NENTWIG, Wolfgang, PERGL, Jan., PYSEK, Peter., RABITSCH, Wolfgang., RICCIARDI, Anthony., RICHARDSON, David., SENDEK, Agnieszka., VILÀ, Montserrat., WILSON, John, WINTER, Martin., GENOVESI, Piero and BACHER, Sven. A united classification of alien species based on the magnitude of their environmental impacts. PLOS Biology, 2014, 12(5): 1-11. 
CASTRO, João. Aplicação da Detecção Remota em inventário florestal. PhD thesis presented to Trás-os-Montes, 2004.

CATFORD, Jane, JANSSON, Roland and NILSSON, Christer. Reducing redundancy in invasion ecology by integrating hypotheses into a single theoretical framework. Diversity and Distributions, 2009, 25: 22-38.

DORMANN, Carsten., MCPHERSON, Jana., ARAÚJO, Miguel., BIVAND, Roger., BOLLINGER, Janine., RICHARD, GUDRUN, Carl., DAVIES, Richard., HIRZEL, Alexandre., JETZ, Walter., KISSLING, Daniel., KUHN, Ingolf., OHLEMULLER, Ralf., PEREZ-NETO, Pedro., REINEKING, Bjorn., SCHRODER, Boris., SCHURR, Frank and WILSON, Frank. Methods to account for spatial autocorrelation in the analysis of species distributional data: a review. Ecography, 2007, 30: 609:628.

ELITH, Jane., GRAHAM, Catherine., ANDERSON, Robert., DUDÍk, Miroslav., FERRIER, Simon., GUISAN, Antoine., HIJMANS, Robert., HUETTMANN, Falk., LEATHWICK, John., LEHMANN, Anthony., LI, Jin., LOHMANN, Lucia., LOISELLE, Bette., MANION, Glenn., MORITZ, Craig, NAKAMURA, Miguel., NAKAZAWA, Yoshinori., OVERTON, Jacob., PETERSON, Andrew., PHILLIPS, Steven., RICHARDSON, Karen., SCACHETTI-PEREIRA, Ricardo., SCHAPIRE, Robert., SOBERÓN, Jorge., WILLIAMS, Stephen., WISZ, Mary and ZIMMERMANN, Niklaus. Novel methods improve prediction of species distributions from occurrence data. Ecography, 2006, 29: 129-151.

ELITH, Jane., PHILLIPS, Steven., HASTIE, Trevor., DUDİK, Miroslav., CHEE, Yung and YATES, Colin. A statistical explanation of MAXENT for ecologists. Diversity and distributions, 2011, 17:43-57.

ENGLER, Robin., GUISAN, Antoine., RECHSTEINER, Luca. An improved approach for predicting the distribution of rare and endangered species from occurrence and pseudo-absence data: Modelling species distribution. Journal of Applied Ecology, 2004, 41 (2): 263-274.

FIGUEIREDO, Albano. Desempenho de um modelo de máxima entropia na previsão da distribuição do endemismo Euphorbia piscatória na ilha da Madeira. Cadernos de Geografia. 2008, 26/27: 351-359.

FIGUEIREDO, Albano. Assessing impacts from future climatic scenarios on the distribution of flora and vegetation at Madeira Island. PhD thesis presented to University of Coimbra. 2013.

FIGUEIREDO, Rui. Estrutura da paisagem e modelação da ocupação do solo. Aplicação aos concelhos de Aveiro, Viseu e Guarda. PhD thesis presented to University of Coimbra. 2012.

FREEMAN, Elizabeth and MOISEN Gretchen. A comparison of the performance of threshold criteria for binary classification in terms of predictive prevalence and kappa. Ecological Modelling. 2008, 217: 48-50.

GARCÍA-BERTHOU, Emili., Ballesteros, Enric and SANZ-ELORZA, Mario. Múltiples orígenes y vías de introducción de las espécies invasoras. In VILÁ, Montserrat., VALADARES, Fernando., TRAVESET, Anna., SANTAMARIA, Luis and CASTRO, Pilar. A test with a novel combined modelling approach. Invasiones Biológicas. Madrid: Consejo Superior de Investigaciones Cinetíficas, 2008 p. 29-40.

GRAHAM, Catherine., FERRIER, Simon., HUETTMAN, Falk., MORITZ, Craig and PETERSON, Andrew. New developments in museum-based informatics and applications in biodiversity analysis. TRENDS in Ecology and Evolution, 2004, 19 (9): 498-500.

GRAHAM, M.H.. Confronting multicollinearity in ecological multiple regression. Ecology 84 (11). 2003, 28092815.

GUISAN, Antoine and ZIMMERMANN, Niklaus. Predictive habitat distribution models in ecology. Ecological Modelling. 2000, 135: 148-158.

GUTIERRES, F., GIL, A., REIS, E., LOBO, A., NETO, C., CALADO, H., COSTA, J.C. Acacia saligna (Labill.) H. Wendl in the Sesimbra County: invaded habitats and potential distribution modeling. Journal of Coastal Research, S I 64 (Proceedings of the 11th International Coastal Symposium), 2011, Poland.

HERNANDEZ, Pilar., GRAHAM, Catherine., MASTER, Lawrence and ALBERT Deborah. The effect of sample size and species characteristics on performance on different species distribution modelling methods. Ecography, 2006, 29: 773-785.

LIU, Canran., BEERY, Pam., DAWSON, Terrence and PEARSON, Richard. Selecting thresholds of occurrence in the prediction of species distributions. Ecography, 2005, 28: 285-293. 
LIU, Canran., WHITE, Matt and NEWWLL, Graeme. Selecting thresholds for the prediction of species occurrence with presence-only data. Journal of biogeograpgy 2013, 40: 778-789.

LOBO, Jorge., JIMÉNEZ-VALVERDE, Alberto and REAL, Raimundo. AUC: a misleading measure of the performance of predictive distribution models. Global Ecology and Biogeography, 2008, 17:145-151.

LORENZO, P., PAZOS-MALVIDO, E., GONZÁLEZ, L., REIGOSA, M.J.. Allelopathic interference of invasive Acacia dealbata: physiological effects. Allelopathy Journal. 2008, 22 (2): 452-462.

LOWRY, Edward., ROLLINSON, Emily.,LAYBOURN, Adam, SCOTT, Tracy., AIELLO-LAMMENS, Matthews., GRAY. Sarah., MICKLEY, James and GUREVITCH Jessica. Biological invasions: a field synopsis, systematic review and database of the literature. Ecology and Evolution, 2013, 3 (1): 182-191.

MANEL, Stéphanie., WILLIAMS, Ceri and ORMEROD, Stephen. Evaluating presence-absence models in ecology: the need to account for prevalence. Journal of Applied Ecology, 2001, 38: 921-931.

MARCHANTE, Elizabete., FREITAS, Helena and MARCHANTE, Hélia. Guia prático para identificação de plantas invasoras em Portugal. Coimbra: Imprensa da Universidade de Coimbra. 2008. ISBN 978-989-8074-70-6

MARCHANTE, Hélia., MORAIS, Maria., FREITAS, Helena and MARCHANTE, Elizabete. Guia prático para identificação de plantas invasoras em Portugal. Coimbra: Imprensa da Universidade de Coimbra. 2014. ISBN 978-989-26-0785-6.

MARCHANTE, Hélia, FREITAS, Helena and HOFFMAN, John. Assessing the suitable and safety well-known budgalling wasp, Trichilogaster acaciaelongifoliae, for biological control of Acacia longifolia in Portugal. Biological control, 2011, 56: 193-201.

MEA, Millenium Ecosystem Assessment. Ecosystems and human well-being: synthesis report. Washington, DC. 2005, Available at http://www.millenniumassessment.org/ on 7/06/2009.

MCPHERSON, Jana., JETZ, Walter and ROGERS, David. The effects of species range sizes on the accuracy of distribution models: ecological phenomenon or statistical artefact? Journal of Applied Ecology, 2004, 41: 801823.

MONTEIRO-HENRIQUES, Tiago. Fitossociologia e paisagem da bacia hidrográfica do Rio Paiva. PhD thesis presented to University Técnica of Lisboa. 2010.

ORTEGA-HUERTA, Miguel and MAYER, Andrew. Modelling ecological niches and predicting geographic distributions: a test of six presence-only methods. Revista Mexicana de Biodiversidad, 2008, 79 (1): 205-216.

PAIVA, J. Acacia Mill. In: Talavera, S., Aedo, C., Castroviejo, S., Zarco, C.R., Sáez, L., Salgueiro, F.J., Velayos (eds.), Flora Iberica - Plantas Vasculares de la Peninsula Iberica e Islas Baleares. vol. Vol. VII(I). Real Jardín Botánico, CSIS, Madrid, 1999, pp. 11-25.

PEARSON, Richard., THUILLER, Wilfried., ARAÚJO, Miguel., MARTINEZ-MAYER, Enrique., BROTONS, Lluís., MACLEAN, Colin., MILES, Lera., SEGURADO, Pedro., DAWSON, Terence and LEES David. Model-based uncertainty in species range prediction. Journal of Biogeography, 2006, 33: 1704-1711.

PEREIRA, Jorge., FIGUEIREDO, Albano. Susceptibilidade à invasão por Acacia dealbata Mill. na bacia do rio Mondego: proposta metodológica para avaliação da susceptibilidade em áreas extensas. Atas da $6 \underline{a}$ conferência de software aberto para SIG - SASIG 2015, 2015. ISBN 978-989-732-663-9.

PETERSON, Andrew. Predicting the geography of species invasions via ecological niche modelling. The Quarterly Review of Biology, 2003, 78 (4): 419-430.

PHILLIPS, S.J., ANDERSON, R.P., SCHAPIRE, R.E.. Maximum entropy modeling of species geographic distributions. Ecological Modelling. 2006, 190 (3-4): 231-259.

PIMENTEL, David. Biological invasions: Economic and environmental costs of alien plant, animal and microbe species. New York: CRC Press. 2002.

PYSEK, Petr., RICHARDSON, David., REJMÁNEK, Marcel., WEBSTER, Grady., WILLIAAMSON, Mark and KIRSCHNER, Jan. Alien plants in checklists and floras: towards better communication between taxonomists and ecologists. TAXON, 2004, 53 (1): 131-143. 
RICHARDSON, MarceL., HUI, Cang., NUÑEZ, Martln and PAUCHARD, Aníbal. Tree invasions: patterns, processes, challenges and opportunities. Biol Invasions, 2014, 16: 473-480.

RICHARDSON, David., PYSEK, Petr., REJMÁNEK, Marcel., BARBOUR, Michael, PANETTA, Dane and WEST, Carol. Naturalization and invasion of alien plants: concepts and definitions. Diversity and Distributions, 2000, 6: 93102.

SALA, Osvaldo., CHAPIN, Stuart., ARNESTO, Juan., BERLOW, Eric., Bloomfield, Janine., DIRZO, Rudolfo., HUBERSANWALD, Elisabeth., HUENNEKE, Laura., KACKSON, Robert., KINZIG, Ann., LEEMANS, Rik., LODGE, David., MOONEY, Harold., OESTERHELD, Martin., POFF, N., SYKES, Martin., WALKER, Brian., WALKER, Marilyn and WALL, Diana. Global Biodiversijty Scenarios for the Year 2100. Science, 2000, 287 (5459): 1770-1774.

SIMBERLOFF, Daniel., MARTIN, Jean-Louis., GENOVESI, PIERO., MARIS, Virginie., WARDLE, David., ARONSON, James., COURCHAMP, Franck., GALIL, Bella., GARCÍA-BERTHOU, Emili., PASCAL, Michel., PYSEK, Petr., SOUSA, Ronaldo., Tabacchi and VILÀ, Montserrat. Impacts of biological invasions: what's what and the way forward. Trends in Ecology \& Evolution, 2013, 28 (1): 58-64.

SOBERÓN, Jorge. Niche and area of distribution modeling: a population ecology perspective. Ecography, 2010 33 (1): 159-167.

VICENTE, J.R.. Modelling landscape invasion by alien plants under current and future conditions of climate and land use. PhD thesis presented to University of Porto. 2012.

VILÀ, Montserat., BASNOU, Corina., PYSEK, Petr., JOSEFSSON, Melanie., GENOVESI, Piero., GOLLASH, Stephan., NENTWIG, Wolfgang., OLENIN, Sergej., ROQUES, Alain., ROY, David., HULME, Philip and PARTNERS, Daisie. How well do we understand the impacts of alien species on ecosystem services? A pa-European, cross-taxa assessment. Ecological Society of America, 2010, 8 (1): 135-142.

VILÁ, Montserrat., CASTRO, Pilar and GARCÍA-BERTHOU, Emili. Qué son las invasiones biológicas. In VILÁ, Montserrat., VALADARES, Fernando., TRAVESET, Anna and CASTRO, Luis. A test with a novel combined modelling approach. Invasiones Biológicas. Madrid: Consejo Superior de Investigaciones Cinetíficas, 2008 p. $21-$ 28.

WILLIAMSON, Mark and FITTER, Alastair. The characters of successful invaders. Biological Conservation, 1996, 78 (1-2): 163-170. 